\title{
Generation of oxidising fluids by comminution of fault rocks
}

\section{J. Kameda ${ }^{1 *}$, A. Okamoto ${ }^{2}$}

Abstract

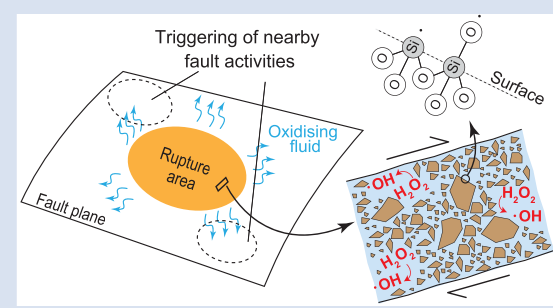

Mechanochemical reactions exert a crucial control on the chemical environments of crustal fault zones during co-seismic and post-seismic periods. Comminution due to faulting causes activation of fault rock surfaces, such as the production of reactive radical species. In this study, we report on the generation of $\mathrm{H}_{2} \mathrm{O}_{2}$ by immersion of comminuted sedimentary, igneous, and metamorphic rocks that are broadly representative of those present at a variety of depths in subduction zones. Our experiments demonstrate that fresh surfaces of these rocks have an $\mathrm{H}_{2} \mathrm{O}_{2}$ productivity of $1.3-10.4 \mathrm{nmol} \mathrm{m}^{-2}$ (mean $=5.4 \mathrm{nmol} \mathrm{m}^{-2}$ ). In a natural fault zone environment, $\mathrm{H}_{2} \mathrm{O}_{2}$ produced after a slip event is likely to react with $\mathrm{Fe}$-bearing mineral surfaces or $\mathrm{Fe}^{2+}$ in porewater, or thermally decompose to produce more oxidative $\cdot \mathrm{OH}$. The oxidising fluid produced by fault rupture in one patch may spread and induce corrosion and degradation of surrounding fault zones. These chemical processes are likely to be important factors influencing the interaction between neighbouring seismic activities.

Received 13 November 2020 | Accepted 20 September 2021 | Published 29 October 2021

\section{Introduction}

Frictional slip on a fault zone causes comminution and wearing of fault rocks, producing highly reactive fine particles (Sammis et al., 1986; Scholz, 2002). Radical species such as Si. and SiO. are commonly created on such particles of silicate minerals owing to homolytic rupture of $\mathrm{Si}-\mathrm{O}$ covalent bonds (Hochstrasser and Antonini, 1972; Narayanasamy and Kubicki, 2005). Hydrogen $\left(\mathrm{H}_{2}\right)$ is a typical product that is generated by reaction between $\mathrm{Si}$. and water molecules within a fault zone. The production of $\mathrm{H}_{2}$ by the interaction of fluids and comminuted rocks has been demonstrated by laboratory experiments (Kita et al., 1982; Kameda et al., 2003; Hirose et al., 2011) and that associated with seismic activity has been observed by field survey (Wakita et al., 1980; Ito et al., 1999). In addition, numerous studies have demonstrated that pulverisation of pure powders of minerals forming igneous rocks can produce oxidising compounds such as hydrogen peroxide $\left(\mathrm{H}_{2} \mathrm{O}_{2}\right)$, superoxide $\left(\mathrm{O}_{2} \cdot{ }^{-}\right)$, and hydroxy $(\cdot \mathrm{OH})$ radicals (Schoonen et al., 2006; Hurowitz et al., 2007; Hendrix et al., 2019), which are termed "reactive oxygen species" or "ROS". ROS are formed by human activities such as mining, which produces fine particles of rocks and minerals (Schoonen et al., 2006). ROS are also formed due to reaction with reactive secondary minerals and photochemistry in soils and sediments (e.g., Georgiou et al., 2015). Because fault activity causes comminution of fault rocks, it can be assumed that ROS are also produced within fault zones. Moreover, such ROS may modify the chemical and even physical state of the fault zone. For example, some lithologies such as shales have been shown to undergo a variety of degradation on interaction with $\mathrm{H}_{2} \mathrm{O}_{2}$ (formation of cracks and voids, decomposition and dissolution of constituent materials, etc.), which results in modification of their hydromechanical properties at varying rates depending on temperature (Chen et al., 2017; Zhou et al., 2018; Yu et al., 2019). Thus, the production and diffusion of oxidising compounds by a seismic event can potentially degrade surrounding fault zones and stimulate subsequent fault activity.

In this study, we examine the production of $\mathrm{H}_{2} \mathrm{O}_{2}$ by reaction between water and ground rock samples at ambient conditions. The samples are sedimentary, metamorphic, and igneous rocks that may constitute plate boundaries at various depths in subduction zones (Hacker et al., 2003; Kimura et al., 2012; Kameda et al., 2017). Our results show that oxidising fluid can be easily produced throughout the plate boundary zone after an earthquake. On the basis of our findings, we discuss the importance of the chemical aspects of fluids on fault behaviours.

\section{Samples and Experimental Methods}

We analysed five natural rock samples: shale and oceanic basalt from the Cretaceous accretionary complex (Shimanto belt, Japan), and three basic schist samples from the high pressure Sanbagawa metamorphic belt, Japan. The basic schist samples (basic schist 1, basic schist 2, and basic schist 3) were taken from the chlorite, garnet, and albite-biotite zones of the Sanbagawa belt, respectively, which correspond to pressure-temperature $(P-T)$ conditions ranging from greenschist to epidote-amphibolite facies ( 300 to $\sim 550^{\circ} \mathrm{C}$; Enami et al., 1994). For comparison, quartz sand (Wako Purer Chemicals) was also used for the experiments.

Whole rock major element concentrations of the rock samples were determined by an $\mathrm{X}$-ray fluorescence spectrometer (XRF; Rigaku 25X Primus IV) using the conventional glass bead method. The $\mathrm{Fe}^{2+} / \Sigma \mathrm{Fe}$ ratios were determined by wet chemical

\footnotetext{
1. Department of Earth and Planetary Sciences, Faculty of Science, Hokkaido University, N10 W8, Sapporo, 060-0810, Japan

2. Graduate School of Environmental Studies, Tohoku University, Sendai, 980-8579, Japan

Corresponding author (email: kameda@sci.hokudai.ac.jp)
} 
analyses. Mineral compositions were analysed by X-ray diffraction analysis (XRD; MAC Science MX-Labo), and the obtained XRD patterns were used for quantitative analysis by RockJock software (Eberl, 2003).

The grinding experiments were carried out by using a planetary-type ball mill apparatus (P6; Fritsch). An amount of $3 \mathrm{~g}$ of each powder was loaded into a zirconia mill pot and was processed at 250-300 rpm for $5 \mathrm{~min}$. The freshly ground powders with the post-grinding grain size of $\sim 0.5 \mu \mathrm{m}$ (estimated from the surface area data described below, assuming uniform spherical particles) were then mixed with pure water (Direct-Q 3UV, Merck; $\mathrm{pH}=5.84$ ) in a Teflon beaker at room temperature $\left(\sim 22{ }^{\circ} \mathrm{C}\right)$, and settled for $10-20 \mathrm{~min}$. The $\mathrm{H}_{2} \mathrm{O}_{2}$ concentrations of the filtered solutions were then measured with the Scopoletin-Horseradish peroxidase (HRP) Fluorometric method using a fluorometer (RF-5300PC; Shimazu). The postexperiment $\mathrm{pH}$ of the solutions was also measured. The specific surface areas of the processed powders were measured by the Brunauer-Emmett-Teller (BET) method using an automated sorption analyser (Autosorb, Quantachrome Instruments). More details on the samples and experimental methods are described in the Supplementary Information.

\section{Results}

Our experiments demonstrated that all of the studied samples were able to produce $\mathrm{H}_{2} \mathrm{O}_{2}$ by mechanical activation and subsequent immersion in water. Figure 1 shows the $\mathrm{H}_{2} \mathrm{O}_{2}$ productivity of each sample $\left(\mathrm{nmol} \mathrm{m}{ }^{-2}\right)$, which is calculated from the $\mathrm{H}_{2} \mathrm{O}_{2}$ concentration of the reacting fluid (the background $\mathrm{H}_{2} \mathrm{O}_{2}$ concentration of $0.060 \mu \mathrm{mol} \mathrm{L}-1$ was subtracted from the measured concentration) normalised to the total surface area of the ground powders, as well as $\mathrm{pH}$ of the reacted solution and $\mathrm{Fe}^{2+}$ content in the solid samples (Tables S-1, S-2). The two analysed quartz samples have values of 0.55 and $0.44 \mathrm{nmol} \mathrm{m}^{-2}$, which are slightly higher than previous results $\left(0.2-0.3 \mathrm{nmol} \mathrm{m}^{-2}\right.$, Hurowitz et al., 2007). Factors such as different temperatures, $\mathrm{pH}$ of the matrix, reaction time, hydration state of the samples, etc. could explain the differences. The $\mathrm{H}_{2} \mathrm{O}_{2}$ productivities of the natural rock samples are generally one order of magnitude greater than those of quartz, ranging from $1.3 \mathrm{nmol} \mathrm{m}^{-2}$ (shale) to $10.4 \mathrm{nmol} \mathrm{m}^{-2}$ (basic schist 3) with a mean value of $\sim 5.4 \mathrm{nmol} \mathrm{m}^{-2}$.

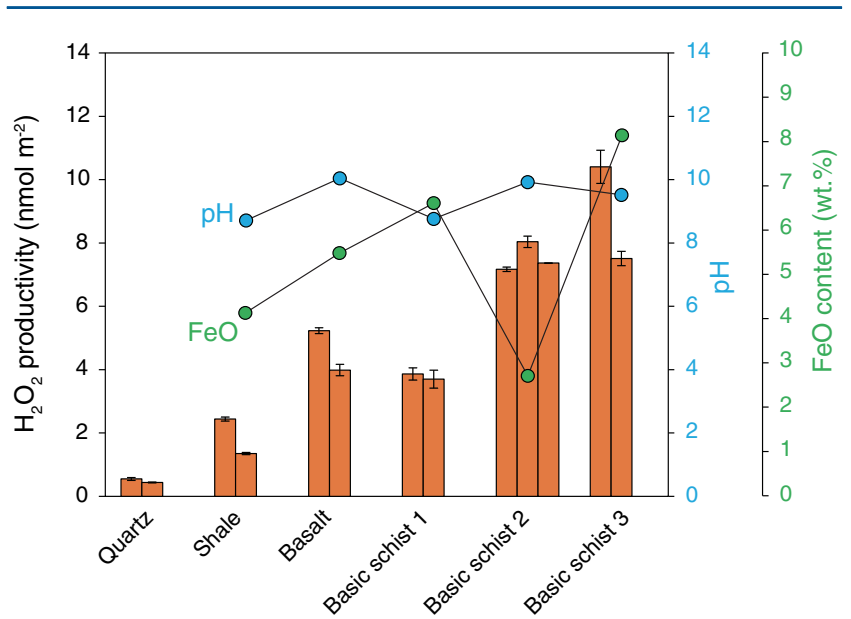

Figure $1 \quad \mathrm{H}_{2} \mathrm{O}_{2}$ productivity of the analysed samples. Error bars for $\mathrm{H}_{2} \mathrm{O}_{2}$ productivity were estimated from the equation for the standard addition method (Larsen et al., 1973). The pH of the solution after the experiment (during the duplicate analyses) and the concentration of $\mathrm{FeO}$ in the rock samples are also shown.
No obvious correlation was found between the $\mathrm{H}_{2} \mathrm{O}_{2}$ productivities and $\mathrm{pH}$ or $\mathrm{Fe}^{2+}$ content.

\section{Discussion}

Although the actual mechanism of $\mathrm{H}_{2} \mathrm{O}_{2}$ production from pulverised mineral surfaces is not completely understood, Hendrix et al. (2019) argued that $\mathrm{Si}-\mathrm{O} \cdot$ on a newly created mineral surface reacts with $\mathrm{H}_{2} \mathrm{O}$ to generate $\mathrm{H}_{2} \mathrm{O}_{2}$ as follows:

$$
2 \equiv \mathrm{Si}-\mathrm{O} \cdot+2 \mathrm{H}_{2} \mathrm{O} \rightarrow 2 \equiv \mathrm{Si}-\mathrm{OH} \cdot+\mathrm{H}_{2} \mathrm{O}_{2}
$$

Hurowitz et al. (2007) conducted pulverisation experiments using various pure mineral types and found that $\mathrm{H}_{2} \mathrm{O}_{2}$ productivity depends on the crystallographic nature of silicate minerals, with productivity increasing with a decreasing number of corners shared between $\mathrm{Si}(\mathrm{Al})$ tetrahedra (here termed the " $c$ " number; Fig. 2). For example, tectosilicate minerals such as quartz and plagioclase have $c=4$ and show the lowest $\mathrm{H}_{2} \mathrm{O}_{2}$ productivity of $<1.0 \mathrm{nmol} \mathrm{m}^{-2}$ of other types of silicate minerals with $c<4$ (Hurowitz et al., 2007; Fig. 2). As the present work used rock samples that included different types of silicate minerals, the weighted mean of $c$ of each sample was estimated by XRD analysis (Table S-3). Figure 2 presents the relationship between $\mathrm{H}_{2} \mathrm{O}_{2}$ productivity and $c$ of the analysed rock samples, and shows that the data are broadly consistent with the results of Hurowitz et al. (2007). Our results reveal that $\mathrm{H}_{2} \mathrm{O}_{2}$ can be generated by activation of natural rocks irrespective of their type (i.e. sedimentary, metamorphic, and igneous rocks), and the amount generated is likely to depend on the mineral composition of the rock.

Stability of $\mathrm{H}_{2} \mathrm{O}_{2}$ in fault zones following slip. Since fault movement causes comminution of fault rocks, $\mathrm{H}_{2} \mathrm{O}_{2}$ is expected to be produced by the reaction with porewater after an earthquake event. Furthermore, larger slip events may also lead to greater amount of comminution (Scholz, 2002; Hirose et al., 2012), which would produce more $\mathrm{H}_{2} \mathrm{O}_{2}$. In a natural fault zone environment, generated $\mathrm{H}_{2} \mathrm{O}_{2}$ reacts with Fe-bearing mineral surfaces or $\mathrm{Fe}^{2+}$ in porewater to produce more oxidative $\cdot \mathrm{OH}$, as follows (i.e. the Fenton reaction):

$$
\mathrm{H}_{2} \mathrm{O}_{2}+\mathrm{Fe}^{2+}+\mathrm{H}^{+} \rightarrow \mathrm{Fe}^{3+}+\cdot \mathrm{OH}+\mathrm{H}_{2} \mathrm{O}
$$

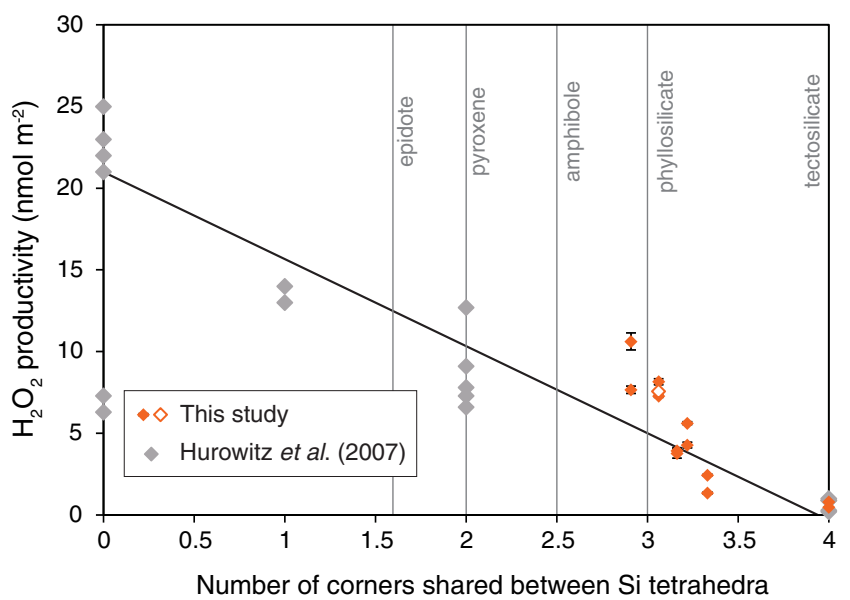

Figure $2 \mathrm{H}_{2} \mathrm{O}_{2}$ productivity vs. number of corners shared between silica tetrahedra (weighted mean) for the analysed rocks. The open symbol is data for the experiment using $0.01 \mathrm{M} \mathrm{NaCl}$ solution. Data and regression line from Hurowitz et al. (2007) are also shown. 
In addition, $\mathrm{H}_{2} \mathrm{O}_{2}$ decomposes to two $\cdot \mathrm{OH}$ at high temperature conditions. The rate coefficient of the decomposition reaction is described as $k=6.4 \times 10^{5} \exp \left(-71 \mathrm{~kJ} \mathrm{~mol}^{-1} / R T\right) \mathrm{s}^{-1}$ (Takagi and Ishigure, 1985). This suggests that the half-life of $\mathrm{H}_{2} \mathrm{O}_{2}$ (i.e. $\ln (2) / k$ ) is $158 \mathrm{~min}$ at $100{ }^{\circ} \mathrm{C}$ but is only $\sim 1 \mathrm{~min}$ at $200{ }^{\circ} \mathrm{C}$. In the supercritical condition $\left(\mathrm{T}>374^{\circ} \mathrm{C}\right)$, the activation energy of the decomposition reaction can be higher $\left(182 \mathrm{~kJ} \mathrm{~mol}^{-1}\right.$; Croiset et al., 2004), but the half-life is again very short (e.g., several seconds at $400{ }^{\circ} \mathrm{C}$ ). Thus, it is presumed that $\mathrm{H}_{2} \mathrm{O}_{2}$ quickly decomposes to $\cdot \mathrm{OH}$ after an earthquake, and fluid containing these oxidative compounds may diffuse along the fault zone.

Influence of oxidising fluid generation on surrounding fault zones. In general, an earthquake does not occur in isolation but occurs as part of a sequence controlled by physical processes such as stress perturbation (Scholz, 2002). Porewater diffusion is usually invoked as a reason for aftershock sequence (e.g., Nur and Booker, 1972), but only the physical aspect of water (i.e. fluid pressure) has been argued in these models. Our study indicates the importance of chemical interaction between the fluid and surrounding fault zones. Specifically, generation of highly oxidising fluid can potentially promote corrosion of nearby fault zones and stimulate further fault activity. Such oxidising fluid is thought to interact with Fe-bearing minerals as well as organic compounds (Chen et al., 2017; Zhou et al., 2018). $\cdot \mathrm{OH}$ oxidises even graphite (Wang and Zhang, 2018), a common product of the thermal maturation of organic compounds in metamorphic rocks, and may therefore degrade fault zones containing such minerals and materials. In natural examples, degradation or consumption of graphite has been observed in some fault zones (Nishiyama et al., 1990; Kretz, 1996; Nakamura et al., 2015), and the involvement of oxidising fluids in these processes has been suggested (Nishiyama, 1990; Okamoto et al., 2021). In addition to mechanical processes, oxidative corrosion could promote such graphite degradation. However, it has not been fully clarified how the redox state of a fault temporally and spatially changes during the seismic cycle. For a more quantitative consideration, the kinetics of the reaction between oxidising fluid and various types of fault rocks and the lifetime of oxidising state of the fluid need to be clarified in future work, as well as how such fluid can affect the shear strength and frictional properties of the rock.

\section{Acknowledgments}

We are grateful to Norifumi Abo (Central Institute of Isotope Science, Hokkaido University) for technical assistance. We also acknowledge two anonymous reviewers and editor Satish Myneni for their constructive comments, which greatly improved the manuscript. The analysers (Quantachrome Autosorb) are registered in the Open Facility system managed by the Global Facility Center, Creative Research Institution, Hokkaido University.

\section{Editor: Satish Myneni}

\section{Additional Information}

Supplementary Information accompanies this letter at https:// www.geochemicalperspectivesletters.org/article2131.

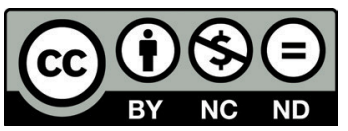

(C) 2021 The Authors. This work is distributed under the Creative Commons Attribution NonCommercial No-Derivatives 4.0 License, which permits unrestricted distribution provided the original author and source are credited. The material may not be adapted (remixed, transformed or built upon) or used for commercial purposes without written permission from the author. Additional information is available at https://www. geochemicalperspectivesletters.org/copyright-and-permissions.

Cite this letter as: Kameda, J., Okamoto, A. (2021) Generation of oxidising fluids by comminution of fault rocks. Geochem. Persp. Let. 19, 32-35.

\section{References}

Chen, Q., Kang, Y., You, L., Yang, P., Zhang, X., Cheng, Q. (2017) Change in composition and pore structure of Longmaxi black shale during oxidative dissolution. International Journal of Coal Geology 172, 95-111.

Croiset, E., Rice, S.F., Hanush, R.G. (2004) Hydrogen peroxide decomposition in supercritical water. Reactors, Kinetics, and Catalysis 43, 2343-2352.

EBERL, D.D. (2003) User's guide to RockJock-A program for determining quantitative mineralogy from powder X-ray diffraction data. USGS Open-file Report 03-78.

Enami, M., Wallis, S.R., Banno, Y. (1994) Paragenesis of sodic pyroxene-bearing quartz schists: implications for P-T history of the Sanbagawa belt. Contributions to Mineralogy and Petrology 116, 182-198

Georgiou, C.D., Sun, H.J., McKay, C.P., Grintzalis, K., Papapostolou, I., Zisimopoulos, D., Panagiotidis, K., Zhang, G., Koutsopollou, E., Christidis, G.E., MargiolaKI, I. (2015) Evidence for photochemical production of reactive oxygen species in desert soils. Nature Communications 6, 7100, doi: $10.1038 /$ ncomms 8100 .

Hacker, B.R., PeAcock, S.M., Abers, G.A., Holloway, S.D. (2003) Subduction factory 2. Are intermediate-depth earthquakes in subducting slabs linked to metamorphic dehydration reactions? Journal of Geophysical Research: Solid Earth 108, 2030, doi: 10.1029/2001JB001127.

Hendrix, D.A., Port, S.T., Hurowitz, J.A., Schoonen, M.A. (2019) Measurement of $\mathrm{OH}^{*}$ generation by pulverized minerals using electron spin resonance spectroscopy and implications for the reactivity of planetary regolith. GeoHealth 3, 28-42, doi: 10.1029/2018GH000175.

Hirose, T., Kawagucci, S., SuzuKi, K. (2011) Mechanoradical $\mathrm{H}_{2}$ generation during simulated faulting: Implications for an earthquake-driven subsurface biosphere. Geophysical Research Letters 38, L17303, doi: 10.1029/ 2011GL048850.

Hirose, T., Mizoguchi, K., Shimamoto, T. (2012) Wear processes in rocks at slow to high slip rates. Journal of Structural Geology 38, 102-116, doi: 10.1016/j.jsg. 2011.12.007.

Hochstrasser, G., Antonini, J.F. (1972) Surface states of pristine silica surfaces I. ESR studies of Es' dangling bonds and of $\mathrm{CO}_{2}$-adsorbed radicals. Surface Science 32, 644-664.

Hurowitz, J.A., Tosca, N.J., McLennan, S.M., Schoonen, M.A.A. (2007) Production of hydrogen peroxide in Martian and lunar soils. Earth and Planetary Science Letters 255, 41-52, doi: 10.1016/j.epsl.2006.12.004

Ito, T., Nagamine, K., Yamamoto, K., Adachi, M., Kawabe, I. (1999) Preseismic hydrogen gas anomalies caused by stress-corrosion process preceding earthquakes. Geophysical Research Letters 26, 2009-2012.

Kameda, J., Saruwatari, K., TANAKA, H. (2003) $\mathrm{H}_{2}$ generation in wet grinding of granite and single-crystal powders and implications for $\mathrm{H}_{2}$ concentration on active faults. Geophysical Research Letters 30, 2063, doi: 10.1029/ 2003GL018252.

Kameda, J., Inoue, S., Tanikana, W., Yamaguchi, A., Hamada, Y., Hashimoto, Y., KIMURA, G. (2017) Alteration and dehydration of subducting oceanic crust within subduction zones: implications for decollement step-down and plate-boundary seismogenesis. Earth Planets and Space 69, 52, doi: 10. 1186/s40623-017-0635-1.

Kimura, G., Yamaguchi, A., Hojo, M., Kitamura, Y., Kameda, J., Ujine, K., Hamada, Y., HamaHASHI, M., Hina, S. (2012) Tectonic mélange as fault rock of subduction plate boundary. Tectonophysics 568, 25-38.

KITA, I., MAtsuo, S., WaKITA, H. (1982) $\mathrm{H}_{2}$ generation by reaction between $\mathrm{H}_{2} \mathrm{O}$ and crushed rock: An experimental study on $\mathrm{H}_{2}$ degassing from the active fault zone. Journal of Geophysical Research: Solid Earth 87, 10789-10795.

KRETZ, R. (1996) Graphite deformation in marble and mylonitic marble, Grenville Province, Canadian Shield. Journal of Metamorphic Geology 14, 399-412.

Larsen, I.L., Hartmann, N.A., Wagner, J.J. (1973) Estimating precision for the method of standard additions. Analytical Chemistry 45, 1511-1513.

Nakamura, Y., Oohashi, K., Toyoshima, T., Satish-Kumar, M., AKai, J. (2015) Straininduced amorphization of graphite in fault zones of the Hidaka metamorphic belt, Hokkaido, Japan. Journal of Structural Geology 72, 142-161. 
Narayanasamy, J., Kubicki, J.D. (2005) Mechanism of Hydroxyl Radical Generation from a Silica Surface: Molecular Orbital Calculations. The Journal of Physical Chemistry B 109, 21796-21807.

NisHIYAMA, T. (1990) $\mathrm{CO}_{2}$-metasomatism of a metabasite block in a serpentine mélange from the Nishisonogi metamorphic rocks, southwest Japan. Contributions to Mineralogy and Petrology 104, 35-46.

Nur, A., Booker, J.R. (1972) Aftershocks caused by pore fluid flow? Science 175 $885-887$.

Okamoto, A., Oyanagi, R., Yoshida, K., Uno, M., Shimizu, H., Satish-Kumar, M. (2021) Rupture of wet mantle wedge by self-promoting carbonation. Communications Earth \& Environment 2, 151, doi: 10.1038/s43247-021. 00224-5.

Sammis, C.G., Osborne, R.H., Anderson, J.L., Banerdt, M., White, P. (1986) Selfsimilar cataclasis in the formation of fault gouge. Pure and Applied Geophysics 124, 53-78.

Scholz, C.H. (2002) The mechanics of earthquake and faulting. Second Edition, Cambridge University Press, Cambridge.

Schoonen, M.A.A., CoHn, C.A., RoEmer, E., LAFFers, R., Simon, S.R., O'Riordan, T. (2006) Mineral-induced formation of reactive oxygen species. Reviews in Mineralogy and Geochemistry 64, 179-221.

TAKAGI, J., IsHIGURE, K. (1985) Thermal decomposition of hydrogen peroxide and its effect on reactor water monitoring of boiling water reactors. Nuclear Science and Engineering 89, 177

Wakita, H., Nakamura, Y., Kita, I., FujII, N., Notsu, K. (1980) Hydrogen release: New indicator of fault activity. Science 210, 188-190, doi: 10.1126/ science.210.4466.188.

WANG, X., ZHANG, L. (2018) Green and facile production of high-quality graphene from graphite by the combination of hydroxyl radical and electrical exfoliation. RSC Advances 8, 40621.

YU, W.G., LeI, J., WANG, T., ChEN, W. (2019) $\mathrm{H}_{2} \mathrm{O}_{2}$-enhanced shale gas recovery under different thermal conditions. Energies 12, 2127, doi: 10.3390/ en12112127.

ZHou, Y., LeI, Y., CHENG, W., YU, W. (2018) Enhance low temperature oxidization of shale gas recovery using hydrogen peroxide. Journal of Petroleum Science and Engineering 164, 523-530. 